\title{
Mechanical Properties of Thermoplastic Variable-Angle Composite Laminations for Conical Shells
}

\author{
Z. Y. Han, ${ }^{a}$ Y. H. Li, ${ }^{\text {b }}$ and H. Y. Fu ${ }^{\mathrm{a}, 1}$ \\ a School of Mechatronics Engineering, Harbin Institute of Technology, Harbin, China \\ ${ }^{\mathrm{b}}$ College of Mechanical Engineering, Hebei University of Science and Technology, Shijiazhuang, \\ China \\ ${ }^{1}$ hongyafu@hit.edu.cn
}

УДК 539.4

\section{Механические свойства термопластичных слоистых композитов с переменным углом для конических оболочек}

\author{
3. Я. Хан ${ }^{\mathrm{a}}$, Я. Х. Ли \\ a Факультет мехатронной техники, Харбинский технологический институт, Харбин, Китай \\ ${ }^{\sigma}$ Факультет машиностроения, Хэбэйский научно-технологический университет, Шиджиажуанг, \\ Китай
}

Технология автоматической укладки термопластичного композитного волокна, являющаяся одной из радикальных технологий получения больших или очень больших компонентов композитов с комплексными формами поверхности, иироко используется в авиационно-космической промылиенности. В качестве объектов исследования использовали восемь групп слоисmых материалов с различными углами конструктивного размещчения, которые были созданы с помощью алгоритма размещчения переменного угла конической оболочки. Представлены алгоритм размещения переменного угла для конической оболочки и модель на основе метода конечных элементов для термопластичных слоистых композитов с переменным углом. Для каждой группы материалов проведены статистический анализ, исследование методом разложения по собственным формам и расчет устойчивости. Установлено, что зависимость напряжение-деформация, модальная прочность и прочность при продольном изгибе слоистьх материалов с переменным углом периодически изменяются в зависимости от угла конструктивного размещения.

Ключевые слова: термопластичный композит, технология автоматической укладки волокна, слоистые материалы с переменным углом, зависимость напряжение-деформация, модальная прочность, прочность при продольном изгибе.

Introduction. With the continuous development of science and technology, composite materials have demonstrated their superior performance and are widely studied and used in production of almost all areas of life, such as damping structure design $[1,2]$, biomimetic prostheses [3], commercial aircraft [4], carbon nanotube reinforcing [5], etc. This paper focuses on the mechanical properties of thermoplastic composite variable-angle laminations for conical shells. These laminations are produced by automated fiber placement technology. Automated fiber placement technology, as one of the extreme manufacturing technologies for large or extra large composite components with complex surface shapes, has been widely used in the field of aerospace vehicles. In the practical engineering application, taking into consideration the manufacturing complexity of the composite laminations and such influencing factors as tension, compression and shear, laminated composite structure 
is mainly manufactured by overlaying laminations of $0, \pm 45$, and $90^{\circ}$ in a certain order. The unicity of the fiber direction makes the composite material unable to properly demonstrate its directional characteristics, which greatly limits the design flexibility of the composite laminations. In recent years, with the development of automated fiber placement technology, the constant change of fiber placement angle in the same lamination becomes possible. Thus, many scholars start to investigate the phenomenon of change in overall mechanical properties of the laminations caused by fiber placement angle variation. The laboratory of Prof. Gürdal in Delft University Technology of Netherland has conducted research in the variable-angle lamination characteristics of the composite components of various shapes. Hyer studied the laminated composite plate with holes using wavy fibers instead of straight ones. Based on the above study, Gürdal proposed the concept of variable-angle fiber placement and applied it into practice. Lopes, one of the laboratory members, has constructed a finite element model of the variable angle laminated plate, and carried out buckling load and first layer failure analyses [6]. Blom studied the variable-angle trajectory planning algorithms for cylindrical and conical shells, the static and dynamic characteristics of the variable-angle laminations made by the above algorithms [7, 8]. In addition, Wu et al, from Queen's University of Belfast in England, provided a new kind of mathematic definition to describe the fiber direction angle, and conducted buckling analysis and optimization of the variable-angle laminated composite plate [9]. In that research, Rayleigh-Ritz method was adopted to determine the distribution of the pre-buckling and critical buckling loads, while the fiber direction angle was optimized based on the optimization objective of maximizing the buckling load. Akhavan from the University of Porto in Portugal investigated the natural frequency and vibration mode of the rectangle laminated composite plate where the fiber placement angle varied linearly along the coordinate axis [10].

However, the above studies did not consider the overlap and the gap of adjacent towpregs, which affect the shape accuracy of composite components, increase operation times of cut and re-send, and have a great impact on the overall mechanical properties. So in this paper, a new variable-angle trajectory planning algorithm for a conical shell, which can avoid the overlap and the gap, is proposed. Based on this algorithm for conical shell proposed by author [11], this paper performs finite element modeling from three aspects, which are stress-strain, modal and linear buckling, aiming to find the rules of the change between the mechanical properties of the laminations and the initial placement angle.

Variable-Angle Trajectory Planning Algorithm for a Conical Shell. Overlap and gap of adjacent towpregs would, on one hand, affect the shape accuracy of composite components, and increase operation times of cut and re-send. On the other hand, they have a strong impact on the overall mechanical properties. Therefore, the main purpose of the trajectory planning algorithm for the automatic fiber placement is to design reasonable placement paths in order to reduce or eliminate the gap or the overlap of adjacent towpregs. A variable-angle trajectory planning algorithm has been proposed by Han et al. [11].

Equations (1) and (2) are used for calculation of placement angle and trajectory point, respectively [6]:

$$
\begin{gathered}
\cos \varphi=\frac{d l}{d \lambda}, \\
\beta(s)=\int_{s_{0}}^{s} \tan \left(\arccos \left(\frac{N b c}{2 \pi r(l) \cos \gamma}\right)\right) \frac{d s}{s \sin \alpha},
\end{gathered}
$$

where $\varphi$ is the placement angle, $l$ is the distance from the arbitrary point along generatrix to the small end, $\lambda$ is the arc length of the trajectory line, $N$ is the number of trajectory lines, $b$ is the theoretical width of a single towpreg, $c$ is the number of towpregs for single 
trajectory lines, $r(l)$ is the radius of arbitrary cross section along axis, $\alpha$ is the cone opening semi-angle, $\gamma$ is the set placement angle for the initial point, $s$ is the distance from the arbitrary point to the center of the developed conical shell, and $\beta(s)$ is the angle between the horizontal axis and section $s$ on the developed conical shell. The formulas for calculation of the above parameters can be obtained from [11].

Finite Element Model of Variable-Angle Laminations. In this paper, APC-2 (AS4/PEEK) is chosen as the lamination material for the finite element modeling and analysis. The material parameters of APC-2 towpreg are summarized below: elastic moduli $E_{1}=131 \mathrm{GPa}$ and $E_{2}=8.7 \mathrm{GPa}$, shear moduli $G_{12}=5.0 \mathrm{GPa}, G_{13}=5.0 \mathrm{GPa}$, and $G_{23}=1.79 \mathrm{GPa}$, and Poisson's ratio $\mu_{12}=0.28$.

The steps of finite element modeling for variable angle laminations in the ABAQUS are as follows. Firstly, the element type is chosen, and the laminations are discretized; secondly, the nodes and elements are numbered; then, the material properties for each element are set; finally, the stacking sequences of laminations are set. An S4 shell element with four integration points is chosen as the element type for finite element modeling and analysis, whereas Fig. 1 shows the laminations' discretization, nodal and element labels. In the ABAQUS, the local coordinate system is used for shell element. The conical shell is a kind of revolved body, so the cylindrical coordinate system is chosen as the local coordinate system. The APC-2 towpreg has an orthogonal anisotropy, so that the material properties of each element are related to placement angle at the center point of each element. Therefore, the local material properties can be set by rotation of the local coordinate system.

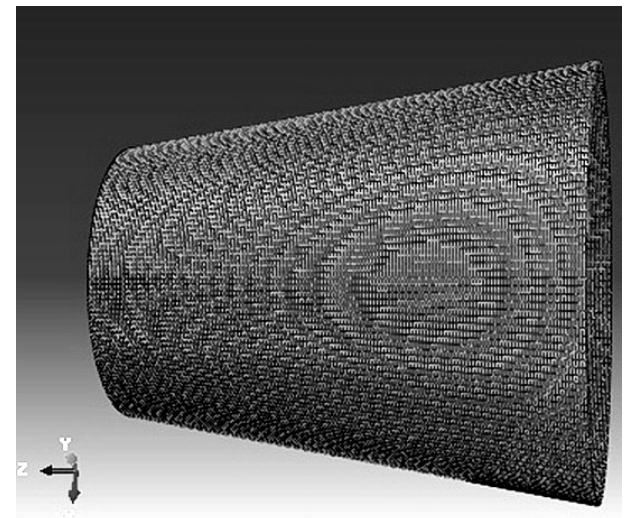

a

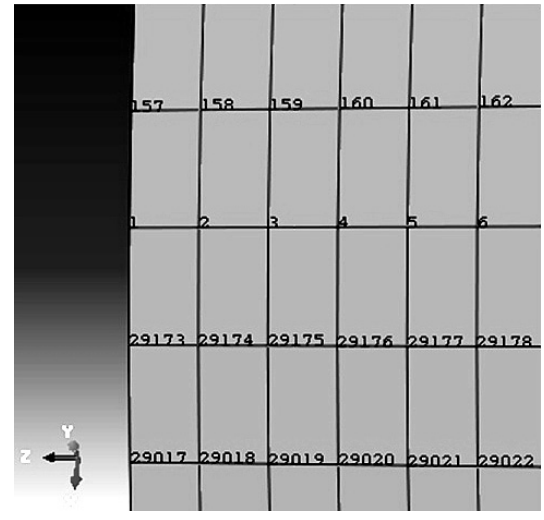

b

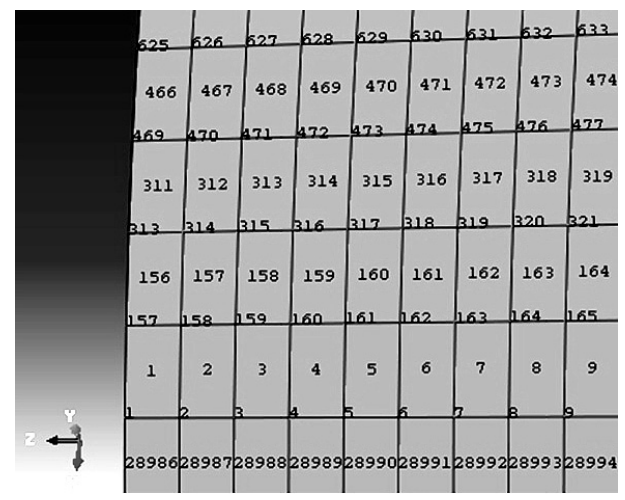

c

Fig. 1. Finite element model of variable-angle laminations: discretization (a), nodal (b) and element (c) data. 
$\mathrm{T}$ a b 1 e 1

Parameters of Laminations for a Conical Shell

\begin{tabular}{|c|c|c|c|c|}
\hline Group & $\begin{array}{l}\text { Placement } \\
\text { angle } \\
\text { (small end) }\end{array}$ & $\begin{array}{l}\text { Placement } \\
\text { angle } \\
\text { (large end) }\end{array}$ & $\begin{array}{l}\text { Number } \\
\text { of tow } \\
\text { (single } \\
\text { lamination) }\end{array}$ & Stacking sequence \\
\hline 1 & $\begin{array}{c}11.06^{\circ} \\
-11.06^{\circ}\end{array}$ & $\begin{array}{c}50.80^{\circ} \\
-50.80^{\circ}\end{array}$ & 185 & $<(11.06,50.80)_{5} \mid(-11.06,-50.80)_{5}>_{4}$ \\
\hline 2 & $\begin{array}{c}20.12^{\circ} \\
-20.12^{\circ} \\
\end{array}$ & $\begin{array}{c}52.79^{\circ} \\
-52.79^{\circ}\end{array}$ & 177 & $<(20.12,52.79)_{5} \mid(-20.12,-52.79)_{5}>_{4}$ \\
\hline 3 & $\begin{array}{c}30.16^{\circ} \\
-30.16^{\circ} \\
\end{array}$ & $\begin{array}{c}56.17^{\circ} \\
-56.17^{\circ} \\
\end{array}$ & 163 & $<(30.16,56.17)_{5} \mid(-30.16,-56.17)_{5}>_{4}$ \\
\hline 4 & $\begin{array}{c}40.21^{\circ} \\
-40.21^{\circ}\end{array}$ & $\begin{array}{c}60.54^{\circ} \\
-60.54^{\circ}\end{array}$ & 144 & $<(40.21,60.54)_{5} \mid(-40.21,-60.54)_{5}>_{4}$ \\
\hline 5 & $\begin{array}{c}50.09^{\circ} \\
-50.09^{\circ} \\
\end{array}$ & $\begin{array}{c}65.60^{\circ} \\
-65.60^{\circ} \\
\end{array}$ & 121 & $<(50.09,65.60)_{5} \mid(-50.09,-65.60)_{5}>_{4}$ \\
\hline 6 & $\begin{array}{c}60.12^{\circ} \\
-60.12^{\circ} \\
\end{array}$ & $\begin{array}{c}71.29^{\circ} \\
-71.29^{\circ} \\
\end{array}$ & 94 & $<(60.12,71.29)_{5} \mid(-60.12,-71.29)_{5}>_{4}$ \\
\hline 7 & $\begin{array}{c}70.19^{\circ} \\
-70.19^{\circ} \\
\end{array}$ & $\begin{array}{c}77.40^{\circ} \\
-77.40^{\circ}\end{array}$ & 64 & $<(70.19,77.40)_{5} \mid(-70.19,-77.40)_{5}>_{4}$ \\
\hline 8 & $\begin{array}{c}79.96^{\circ} \\
-79.96^{\circ}\end{array}$ & $\begin{array}{c}83.57^{\circ} \\
-83.57^{\circ}\end{array}$ & 33 & $<(79.96,83.57)_{5} \mid(-79.96,-83.57)_{5}>_{4}$ \\
\hline
\end{tabular}

Eight groups of variable-angle laminations are analyzed by the finite element method. The relative information of each lamination group is illustrated in Table 1. Each group consists of 40 symmetrically arranged laminations with $0.2 \mathrm{~mm}$ thickness each. In the last column of Table 1, the stacking sequence of laminations is listed as follows: " $<$ (placement angle at the small end, placement angle at the large end $)_{s} \mid$ (placement angle at the small end, placement angle at the large end $)_{S}>_{S}$." Here sign "|" stands for the separator of laminations, while the particular value of $s$ sindicates the number of laminations.

Stress and Strain Analysis for Variable-Angle Laminations. In this section, the static analysis is conducted for eight variable-angle lamination groups tabulated in Table 1. Both ends of the conical shell are fully constrained, and pressure of $10^{6} \mathrm{~Pa}$ directed towards the outer surface is applied to the inner surface of the conical shell. Figure $2 \mathrm{a}$ shows the maximum strain of eight variable-angle laminations groups, while Figs. $2 b$ and $2 \mathrm{c}$ show the strain distribution of the 1st and 6th lamination groups in the axial direction, respectively.

From Fig. 2a it can be seen that the maximum strain value exhibits the initial decrease followed by a further increase: the initial placement angle at the small end monotonously increases with the serial number of the group, whereas the difference between the maximum strain values of the 1 st and the 6th lamination groups is about $2 \%$. For large or extra large components, a possibility of reducing deformation by $2 \%$ via changing the placement angle is of practical importance. Taking the 1st lamination group (with the highest maximum strain value) and the 6th one (with the lowest respective value) as examples, strain variations of these two lamination groups along the axial line are shown in Figs. $2 \mathrm{~b}$ and $2 \mathrm{c}$. The small end of each group is located at the starting point of the axial line, while the large end is located at the finishing point of the axial line. Since the value of 


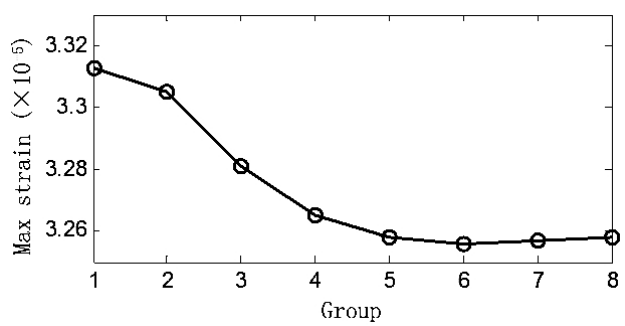

a

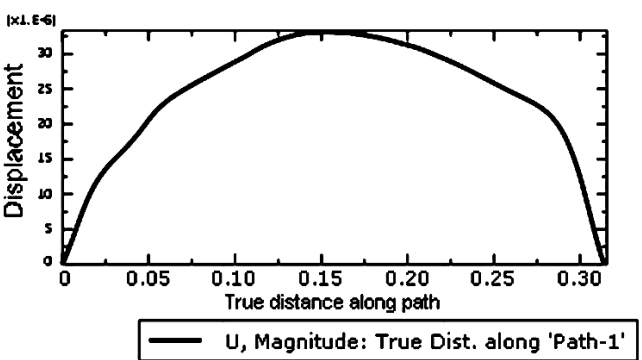

b

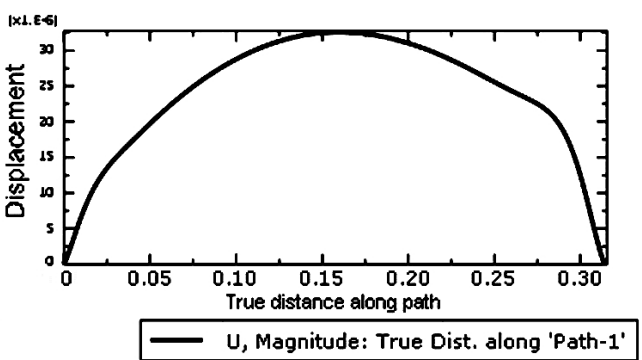

$\mathrm{c}$

Fig. 2. Strain values for 8 variable-angle lamination groups: the maximum strain of 8 variable-angle lamination groups (a), strain distribution of the 1st (b) and 6th (c) lamination groups in the axial direction.

pressure exerted on the internal face of each group is the same, and the laminations are bodies of revolution, the strain of the laminations is distributed in a ring-like pattern; the maximum strain of the laminations is located in the middle of the conical shell, thereby the strain value decreases from the location of the maximum strain to both ends.

Figures $3 \mathrm{a}$ and $3 \mathrm{~b}$ depict the maximum and minimum equivalent stress of these 8 variable angle-lamination groups, respectively, while Figs. $3 \mathrm{c}$ and $3 \mathrm{~d}$ show the equivalent stress distribution of the 1st and 8th lamination groups in the axial direction. From Fig. 3a it can be seen that the maximum equivalent stress value is in the trend of monotonous decrease along with the serial number of the group; whereas, the maximum equivalent stress values of the 1 st and the 8th lamination groups differ by about $2.4 \%$. From Fig. $3 \mathrm{~b}$ one can see that the minimum equivalent stress value manifests a monotonous increase with the serial number of the group; while, the minimum equivalent stress values of the 1 st and the 8 th lamination groups differ by about $10 \%$. The maximum equivalent stress value is one order of magnitude larger than the minimum one. Therefore, if the laminations performance is estimated by the maximum equivalent stress value, the 8 th lamination group would be the one with the optimal performance. Since the maximum equivalent stress value is one order of magnitude higher than the minimum one, the former value is worthy to be especially analyzed. Taking the 1st lamination group (with the highest maximum equivalent stress value) and the 8th one group (with the lowest respective value) as examples, variations of the equivalent stresses in these two lamination groups along the axial line are plotted in Figs. $3 \mathrm{c}$ and $3 \mathrm{~d}$. The small end of a cone for each group is located at the starting point of the axial line, and the large end is located at the finishing point of the axial line. It could be deduced from these plots that the maximum equivalent stresses for these two lamination groups are located near the side of the large end; by comparing the curves in Figs. $3 \mathrm{c}$ and $3 \mathrm{~d}$, it could be observed that variation of the equivalent stress along the axial line in the 8th lamination group is smoother than that of the 1st group. Therefore, as for the lamination equivalent stresses, the 8th lamination group is the one with the optimal performance. In 


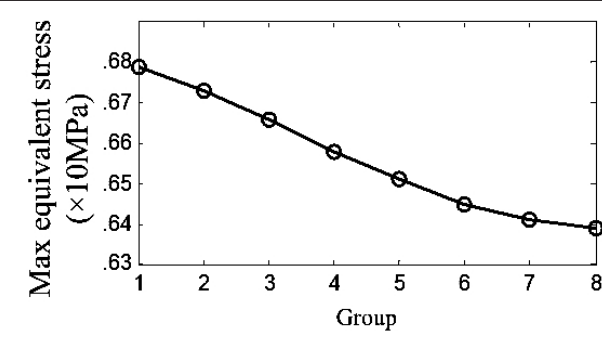

a

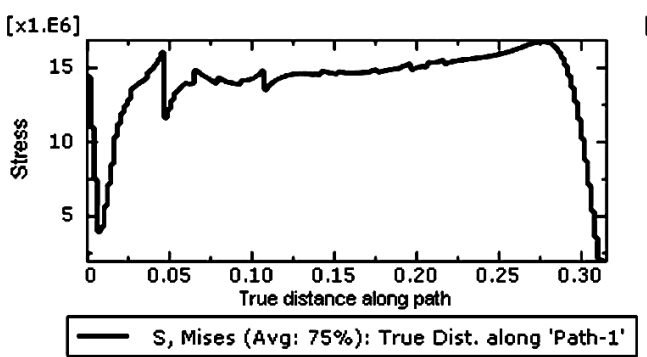

C

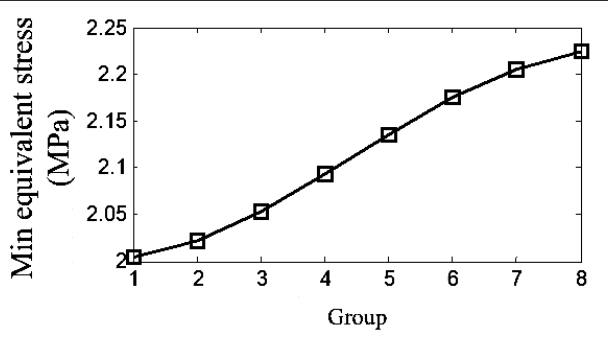

b

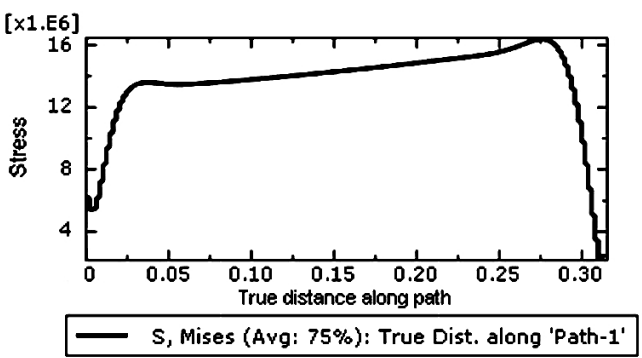

d

Fig. 3. Distibutions of the equivalent stresses in 8 variable angle lamination groups: the maximum (a), the minimum (b), of the 1st (c) and 8th (d) lamination groups in the axial direction.

Figs. $3 \mathrm{c}$ and $3 \mathrm{~d}$, there are some terraced steps of increase or decrease in the curves. After measurement, the width of each step is found to be $2 \mathrm{~mm}$, which coincides with the unit length used in the lamination modeling. The discrete phenomenon of the above equivalent stress is caused by different material attributes in the adjacent units, i.e., the material attribute is discrete because of different placing angles for the adjacent units. The change in the placement angle at the small end of the 1st lamination group is larger than that of the 8 th one, which makes the material attribute discreteness for adjacent units at the small end of the 1st lamination group larger than that of the 8th one. Therefore, the discrete and fluctuating phenomena of the equivalent stress at the small end of the 1 st lamination group are more obvious than those of the 8th one.

Modal Analysis for Variable-Angle Laminations. The main goal of the modal analysis is to determine the vibration performance of the variable-angle laminations, including frequency of each lamination group and its corresponding vibration mode, to provide guidance for lamination design; on the other hand, the modal frequency is the foundation of dynamic analysis on the variable angle lamination (such as the transient state, harmonic response, spectral analysis, etc.). A successful acquisition of the inherent frequency and vibration mode of the variable-angle laminations makes it possible to avoid resonance or vibration at a specific frequency. The ends of the variable-angle laminations for a conical shell are fully constrained. The finite-element software ABAQUS and the Lanczos method are applied to conduct the model analysis on the 8 variable-angle lamination groups depicted in Table 1. Figure 4a shows the frequency curves of the top ten orders for these 8 variable-angle lamination groups.

The eigenvalues and frequencies for each order pair (such as 1-2, 3-4, 5-6, 7-8, and 9-10) have basically the same values, which fact is related to the symmetrical structure of the laminations for a conical shell and the symmetrical constraints. Under the above conditions, the eigenvalues and frequencies of two orders will be equal to each other. The eigenvalue and frequency of the variable-angle lamination structure are related to the fiber placement angle. It can be seen from Fig. 4a that the eigenvalues and frequencies of these 
eight lamination groups manifest a monotonous decrease with the increase of the serial number for groups, whereas the initial placement angle increases with the serial number. By analyzing the frequencies of these 8 lamination groups, it can be observed that the frequency value varies between 10 and $190 \mathrm{~Hz}$ for various initial placement angles. From the above analysis, we can draw a conclusion that by changing the fiber placement angle, the eigenvalue and frequency of the laminations can also be changed. When designing the variable-angle laminations, this feature can be used to design laminations that can meet the overall requirements. In addition, this feature will make it possible to avoid the resonance frequency for structures or systems that are relatively sensitive to vibration.

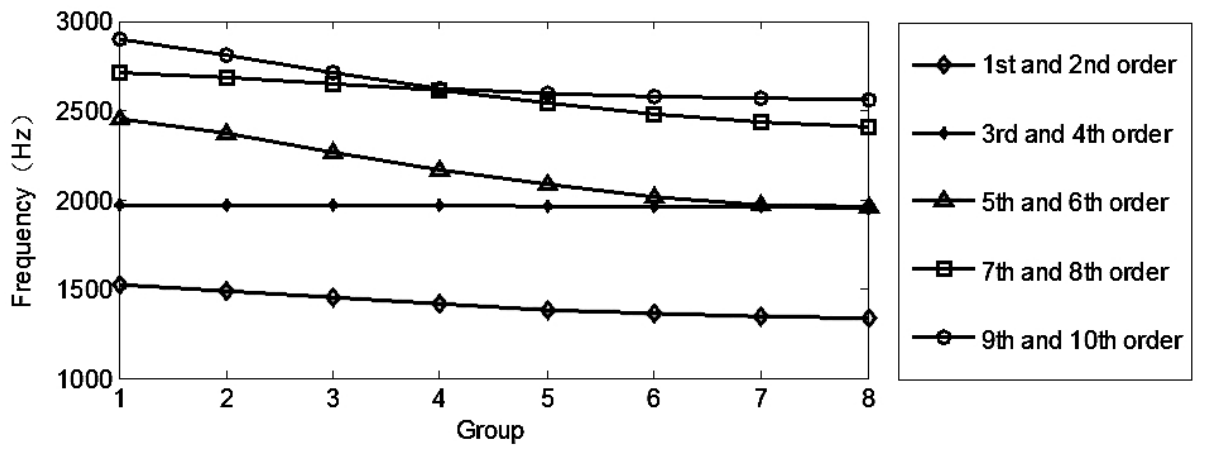

a

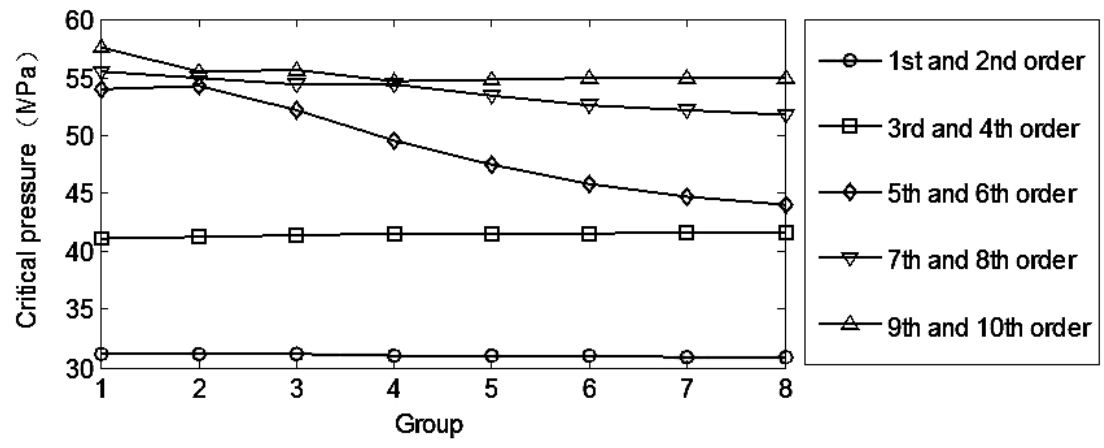

$\mathrm{b}$

Fig. 4. Frequency (a) and the critical pressure (b) curves of the top ten orders for 8 variable-angle lamination groups.

Buckling Strength Analysis for Variable-Angle Laminations. The aim of the linear buckling analysis, which is also called eigenvalue buckling analysis, is to study the critical pressure and the corresponding after-buckling shape of the variable-angle laminations under a specific load. When using the linear buckling analysis to forecast the theoretical buckling strength of the variable-angle laminations, the solution obtained will be nonconservative since the non-linear or initial defects are disregarded. In this section, the Lanczos method is used to conduct the linear buckling analysis for eight variable-angle lamination groups given in Table 1. Both ends of the conical shell are fully constrained, and pressure of $10^{6} \mathrm{~Pa}$ directed towards the inner surface is applied to the outer surface of the conical shell. Figure $4 \mathrm{~b}$ depicts the critical pressure curves of the top ten orders of these eight variable-angle lamination groups.

The critical pressures in each order pair (i.e., 1-2, 3-4, 5-6, 7-8, and 9-10) are nearly the same, similar to the case described in the previous section, due to the symmetry of structure and constraints. Under the above conditions, the critical pressure of two orders 
will be equal to each other. The critical pressure of the variable-angle lamination structure is related to the fiber placement angle. It can be seen from Fig. $4 \mathrm{~b}$ that with the increase in the serial number for groups the critical pressure of order pair 1-2 manifests a monotonous decrease, while that of order pair 3-4 exhibits a monotonous increase. However, for order pairs of 5-6, 7-8, and 9-10, no manifested trends of the critical pressure.variation are observed. In practical applications, the critical pressure of order 1 is often treated as the most critical. Comparison of the critical pressures of order 1 of eight variable-angle lamination groups, the difference between the 1st and the 8th group could reach about $1 \%$.

Conclusions. In this study, the static, modal, and buckling analyses of eight lamination groups with different initial placement angles formed by the conical shell variable-angle placement algorithm have been conducted. This study demonstrates a regular variation of strain, the equivalent stress, frequency and the critical pressure with the initial placement angle values. The main results of this study are as follows:

1. The maximum strain value decreases first and then increases with the increase in the initial placement angle at the small end.

2. The maximum equivalent stress value decreases with the increase in the initial placement angle at the small end. The minimum equivalent stress value increases with the increase in the initial placement angle at the small end.

3. The eigenvalues and frequencies of the studied eight lamination groups decrease with the increase in the initial placement angle at the small end.

4. The critical pressure of orders 1 and 2 of eight variable-angle lamination groups decrease with the increase in the initial placement angle at the small end.

Acknowledgments. This material is based upon work supported by the National Science Foundation of China (Grant No. 51005060) and the Key State Science and Technology Projects of China (Grant No. 2009ZX04004-111).

\section{Р е 3 юм е}

Технологія автоматичного укладання термопластичного композитного волокна, що $€$ однією з радикальних технологій отримання великих або дуже великих компонентів композитів із комплексними формами поверхні, широко використовується в авіаційно-космічній промисловості. Об'єктом дослідження слугували вісім груп шаруватих матеріалів із різними кутами конструктивного розміщення, які отримано за допомогою алгоритма розміщення змінного кута конічної оболонки. Представлено алгоритм розміщення змінного кута для конічної оболонки і модель на основі методу скінченних елементів для термопластичних шаруватих композитів зі змінним кутом. Для кожної групи матеріалів проведено статистичний аналіз, дослідження методом розкладання за власними формами і розрахунок стійкості. Установлено, що залежність напруження-деформація, модальна міцність і міцність при поздовжньому згині шаруватих матеріалів зі змінним кутом періодично змінюються в залежності від кута конструктивного розміщення.

1. A. Hazrati Niyari, "Nonlinear finite element modelling investigation of flexural damping behaviour of triple core composite sandwich panels," Mater. Design, 46, 842-848 (2013).

2. A. Fereidoon and A. Hazrati Niyari, "Investigation of the nonlinear behaviour of damping of aluminum foam core sandwich composite beams," J. Reinf. Plast. Compos., 31, No. 9, 639-653 (2012).

3. A. Gloria, D. Ronca, T. Russo, et al.,'Technical features and criteria in designing fiber-reinforced composite materials: from the aerospace and aeronautical field to biomedical applications," J. Appl. Biomater. Biomech., 9, No. 2, 151-163 (2011). 
4. J. C. Seferis and L. Nicolais, "The role of the polymeric matrix in the processing and structural properties of composite materials," in: Proc. Joint U.S.-Italy Symp. on Composite Materials, Capri, Italy (1981).

5. H. K. Wei, Y. J. Zhang, and H. Y. Gong, "Preparation and characteristics of multiwalled carbon nanotubes reinforced boron carbide composites," Mater. Res. Innov., 13, No. 1, 70-73 (2009).

6. C. S. Lopes, Z. Gürdal, and P. P. Camanho, "Variable-stiffness composite panels: buckling and first-ply failure improvements over straight-fibre laminates," Comput. Struct., 86, No. 9, 897-970 (2008).

7. A. W. Blom, Structural Performance of Fiber-Placed Variable-Stiffness Composite Conical and Cylindrical Shells, Doctoral Dissertation, Netherlands, Delft University of Technology (2010).

8. A. W. Blom, S. Setoodeh, J. M. A. M. Hol, and Z. Gürdal, "Design of variablestiffness conical shells for maximum fundamental eigenfrequency," Comput. Struct., 86, No. 9, 870-878 (2008).

9. Z. M. Wu, P. M. Weaver, G. Raju, and B. C. Kim, "Buckling analysis and optimization of variable angle tow composite plates," Thin-Walled Struct., 60, 163172 (2012).

10. H. Akhavan and P. Ribeiro, "Natural modes of vibration of variable stiffness composite laminates with curvilinear fibers," Comp. Struct., 93, No. 11, 3040-3047 (2011).

11. Z. Y. Han, Y. H. Li, H. Y. Fu, and Z. X. Shao, "Variable angles trajectory planning algorithm of automated fiber placement for conical shell," J. Comp. Design Comp. Graph., 24, No. 3, 400-405 (2012). 